\title{
Wartościowanie poezji w Zarysie literatury polskiej z ostatnich lat szesnastu Piotra Chmielowskiego. Kilka punktów widzenia
}

\section{$\operatorname{Po}($ mimo $)$}

Wydaje się, że historycznoliteracką świadomość ukształtowaną pod wpływem pytania o stosunek autora Zarysu literatury polskiej z ostatnich lat szesnastu ${ }^{\mathrm{I}}$ do poezji zdominowało prawo puenty. W zakończeniu drugiego rozdziału części pierwszej syntezy Piotra Chmielowskiego czytamy:

Bądź-co-bądź, jeżeli owa śmiała, a nawet zuchwała krytyka nie wyrugowała całkowicie nędznych produkcji, to niewątpliwie zmniejszyła ich liczbę. [...] Pisma nasze obecnie nieporównanie mniej drukują poezji, aniżeli przed laty piętnastu; można powiedzieć, że dziś tyleż wierszyków zostaje w koszu redakcyjnym, ile ich poprzednio czytelnikom podawano; a to już zysk wielki $(Z, 45)$.

Fragment ten bardzo dobrze odzwierciedla i cechy stylu autora, i podejmowane przez niego zagadnienia skoncentrowane wokół antagonizmu poezji i deprecjonującej ją młodej krytyki ${ }^{2}$. Może też uzasadniać przekonanie, że to Chmielowski w dużejmierze ukształtował negatywny obraz ówczesnej poezji i zrobił to bardzo sugestywnie?

${ }^{\text {I }}$ P. Chmielowski, Zarys literatury polskiej z ostatnich lat szesnastu, Wilno 1881. Dalej: $Z$.

${ }^{2}$ Duży wpływ na ukształtowanie obrazu tego antagonizmu miał Kazimierz Wóycicki, który swoją znaną książkę poświęcił „Pamięci Piotra Chmielowskiego" i przypisywał mu dzieło „wyparcia poetów z ostatnich stanowisk” - Walka na Parnasie i o Parnas. Materiaby i opracowania do dziejów pozytywizmu polskiego, cz. 1: Walka zepigonizmem: poglady, wskazania, nadzieje, wróżby, Warszawa 1928, s. 167.

3 Zob. J. Tomkowski, Esej o zabijaniu poetów, w: idem, Samobójcy i marzyciele. O zabijaniu poetów, Kielce 2002, s. 13, 22, 35. Zob. też: A. Mazur, J. Tomkowski, Zabijanie poetów, „Ruch Literacki” 1991, z. 4, s. 321. Ma to niewątpliwie związek z „legendotwórczym” charakterem Zarysu - J. Sztachelska, Piotr Chmielowski i legenda pozytyrwizmu, w: Piotr Chmielowski i Antoni Gustaw Bem. 
Przypomnijmy jednak także zdanie pierwsze tego rozdziału: „Minął już był dawno okres wielkiej poezji naszej” $(Z, 29)$. Również ono wyznaczało chronologiczny i problemowy horyzont wypowiedzi krytyka o poezji. Po lekturze tekstu Chmielowskiego trudno przesądzić, która z konstatacji bardziej ważyła na kształtowanym w nim układzie znaczeń. Toteż wolę zatrzymać się na stwierdzeniu, że utrwalony w Zarysie proces wartościowania poezji przebiega $\mathrm{w}$ przestrzeni pomiędzy tymi uwagami. Zgadzam się przy tym z Adamem Makowskim, który udowodnił, że w Chmielowskiego „ekonomii wartości” ważne są nie tylko kryteria, ale i ich uwarunkowania ${ }^{4}$. Chciałabym więc zaproponować konfiguracyjny model lektury Zarysu i kilku innych tekstów krytyka ${ }^{5}$ - ważne wydaje mi się uchwycenie napięć pomiędzy różnymi aspektami poglądów Chmielowskiego. Zasadniczy ruch znaczeń rozpoczyna się tu od przenoszenia uwagi z twórczości wierszowanej na poezję, które nie są tożsame. Dynamikę tego ruchu wzmacniają kontekstualne motywacje wypowiadanych przez Chmielowskiego sądów. Interesują mnie te sądy, choć o nich już pisano ${ }^{6}$, ale także tryb ustalania i zapisywania procesu wartościowania oraz strategie tekstowe autora modelujące przemiany dyskursu oceniającego.

Zacznijmy, wbrew temu, co napisałam w pierwszym zdaniu, od refleksji nad początkiem wspomnianego rozdziału drugiego, który pozwala uznać, że wszystkie opinie autora na temat twórczości poetyckiej kształtowały się w cieniu rozpoznania stawiającego jego pokolenie w pozycji „po” wielkich romantykach. Jakkolwiek konstatacja ta współtworzy dziś zbiór badawczych oczywistości ${ }^{7}$, to warto ją wyeksponować i doprecyzować. Generacyjna synteza Chmielowskiego uwzględnia zarówno sytuację zmiany, początku związanego z aktywnością pozytywistów, jak i atmosferę wyczerpania, końca modelu twórczości dominującego w poprzedniej formacji i niezwykle wysoko cenionego. Nie są one (sytuacja, atmosfera) bynajmniej wobec siebie - co

Konferencja ogólnopolska w 150. rocznicę ich urodzin, red. Z. Przybyła, Częstochowa 1999, s. 41-51.

4 A. Makowski, Metoda krytycznoliteracka Piotra Cbmielowskiego, Warszawa 2001, s. 118. Zob. też: E. Paczoska, Krytyka literacka pozytywistów, Wrocław 1989, s. 159.

5 Będę się koncentrowała na Zarysie z 1881 roku, uznając jego modelowość w części syntetycznej dla kolejnych wariantów czy edycji, które - jeśli chodzi o temat poezji - zmieniają się głównie w części drugiej.

${ }^{6} \mathrm{Z}$ prac nowszych zob. np. A. Owczarek, Chmielowski o poetach $i$ poezji, w: Piotr Chmielowski i Antoni Gustaw Bem, s. 65-75.

7 Zob. E. Warzenica, Pozytywistyczny „obóz mlodych” wobec tradycji wielkiejpolskiejpoezji romantycznej (lata 1866-1881), Warszawa 1968. 
wymaga podkreślenia - w relacji zastępowania, lecz współistnienia, a to oznacza stan kryzysu: kresu i przesilenia. Znaczenie rekonstruowanej przez Chmielowskiego dyskusji o poezji polega więc nie tylko na tym, że dynamizuje ona proces programotwórczy, ale wynika także $\mathrm{z}$ tego, że spór ten staje się jednym z najważniejszych gestów autoidentyfikacji opartych na braku, przeciwstawieniu lub negacji. Zza czarno-białego obrazu wyłania się zatem historia powikłanych zależności i reakcji. Będzie się to przekładało na reguły dyskursu Chmielowskiego. Utrata wielkich mistrzów, o której pisze krytyk, oznacza ich zgon, zamilknięcie lub przemawianie „głosem niezrozumiałym” $(Z, 29)$, a więc przerwanie, odmowę lub nieumiejętność komunikacji. $\mathrm{W}$ ten sposób poezja kojarzona jest $\mathrm{z}$ doświadczeniem deprywacji, a część aprobowanych wartości, których była nośnikiem, zostaje odseparowana od teraźniejszości i usytuowana po stronie przeszłości. Z drugiej zaś strony, twórczość poetycka w wydaniu „epigonów” okazuje się problemem - tym poważniejszym, im bardziej różni się zarówno od aktualnych postulatów w tym zakresie, jak i od wzorów z minionej przeszłości, które deprecjonuje, nieudolnie naśladując ${ }^{8}$. To dlatego zarzut naśladownictwa będzie tak częsty i ważny w książce Chmielowskiego. Ocena współczesnego stanu poezji nie jest w pracy krytyka jakością autonomiczną, lecz wpisana została w bardzo złożoną konfigurację problemów tożsamościowych. W tym sensie - trzeba by wobec tego tak uznać - poezja nie została przez Chmielowskiego niedoceniona, a właśnie dowartościowana jako swoista matryca weryfikacji postaw (poetyckich, pisarskich, kulturowych, życiowych). Dowartościowana jednak - odwróćmy perspektywę nie jako obiekt zainteresowania, lecz jako wewnętrzny problem pokolenia pozytywistów, przeciwnik w walce, którą toczą oni $\mathrm{z}$ samymi sobą $\mathrm{w}$ obawie przed koniecznością uznania marności swoich czasów. Jakkolwiek więc „doskonale wiedzie im się w zakresie portretu negatywnego, obrazu, jakim poeta być nie powinien" ", to w Zarysie kwestia ta wybrzmiewa pełnią znaczeń dopiero wtedy, gdy przypomnimy, że autor już od Przedmowy zdradza tendencje do myślenia uzyskującego wyrazistość w zaprzeczeniach i przeciwstawieniach. Zauważmy, że postawa,

${ }^{8} \mathrm{Na}$ to, że jedną z przyczyn słabości ówczesnej poezji była między innymi nieudolność korzystania z tradycji romantycznej, zwracała już uwagę Ewa Warzenica-Zalewska w książce Przetom scjentystyczny w publicystyce warszaweskiego „obozu młodych”. (Lata 1866-1876), Wrocław 1978, s. 190.

9 J. Kulczycka-Saloni, Dziedzictwo romantyzmu w kulturze okresu pozytywizmu, w: Z polskich studiów slawistycznych, seria 4: Nauka o literaturze, Warszawa 1972, s. 47. 
z którą później identyfikowani są epigońscy poeci, wskazywana jest przez autora jako jedno z ograniczeń, tyleż utrudniających, co krystalizujących jego nastawienie pisarskie. Ustalanie własnych poglądów „Mimo wszystkie wyrzeczenia niepoprawnych czarnowidzów, $[. .$.$] mi mo wszystkie kwilenia istot senty-$ mentalnych, które drżąc lękają się strasznej nawały prozy na krainę ideałów; mimo wszelkie krytyki wsteczników" $(Z, 10)$ służy przekonywaniu, że „[...] na obszarach literatury naszej nie martwota, rozkładowi ulegająca, ale nadziei pełne życie panuje, - życie, znajdujące swój wyraz $\mathrm{w}$ walce różnorodnych pojęći kierunków" $(Z, 10)$, a wreszcie pozwala na konstatację, że w porównaniu z rokiem 1831 „po roku 1864 nie ma tego rozłamu piśmiennictwa na dwa odrębne niejako światy” $(Z, 10)$ - poezji i „produkcji umysłowych” $(Z, 10)$. Już w przedmowie jednak widać, że myślenie o poezji czy kojarzonych z nią postawach wymyka się jednoznaczności i zależy od kontekstu. Próbując dookreślić miejsce pierwszych symptomów, jak powiedziałaby Ewa Warzenica-Zalewska, „scjentystycznego przełomu” זо na kulturowej mapie, Chmielowski zmienia punkty widzenia, a to odsłania różne sposoby myślenia o poezji jako punkcie odniesienia. Tę „punktowość” uznaję za ważną cechę dyskursu Chmielowskiego o poezji. Autor najpierw przypomina, że wystąpienia młodych „porównywano do owego obudzenia się ducha poezji romantycznej" $(Z, 25)$. Następnie zaś przekonuje, że bardziej zasadne byłoby zestawienie $\mathrm{z}$,prądem reformatorskim $\mathrm{w}$ wieku XVIII" $(Z, 25)$, co - biorąc pod uwagę logikę wywodu - można by odczytywać jako zdystansowanie się do poetyckiego profilu poprzedniej epoki literackiej. Tymczasem $\mathrm{w}$ ramach inaczej budowanego dystansu - wobec osiemnastowiecznego racjonalizmu - który służy dookreśleniu zakresów zgodności i niezgodności, dokonuje autor aktu obrony praw praktyk twórczych właściwych dla poezji lub z poezją kojarzonych. Chmielowski dowodzi, że „oświeceniowy” rozsądek nigdy „nie przejmie się głęboką poezją uczuć serdecznych a rzewnych, albo wizji mglistych i fantastycznych" $(Z, 27)$. Oba ostatnie przykłady, a także wcześniejsze porównanie roku 1831 i 1864, potwierdzają, że budowanie generacyjnej autocharakterystyki nie może obyć się bez odwołań do poprzedników, a w ramach takiego postępowania trudno jest uniknąć - nazwijmy to - argumentu poezji. Z tego powodu wartościowanie poezji w Zarysie będzie nie tylko funkcją prezentacji profilu pokolenia, ale też niezbędnym jego elementem.

то E. Warzenica-Zalewska, op.cit., s. 34-46. 


\section{Przeciw}

Profil ów, widziany z perspektywy ocen poezji, krystalizuje się na fundamencie nie tyle wspólnoty przeświadczeń, ile wspólnoty racji; w oparciu nie o dyskurs argumentów, lecz zarzutów. Ofensywność tekstu Chmielowskiego i retorykę dominacji świetnie widać w deprecjonujących określeniach „wierszyków” (np. $Z, 31)$ i „wierszydeł” $(Z, 45)$. Krytykuje się je przede wszystkim za wyższość uczuć nad myślami i formy nad treścią. A uszczegóławiając: $\mathrm{z}$ powodu ujawnianych stanów emocjonalnych $-\mathrm{za}$ „niepotrzebne rozmarzenie” $(Z, 32)$, „ckliwą rozpacz” $(Z, 32)$, smutek, melancholię; pod względem sposobów ich wyrażania za egzaltację i przesadę; w zakresie stosowanej formy - za manierę, powtarzanie, naśladownictwo, pustą frazeologię; z uwagi na psychologiczną wiarygodność - za brak autentyzmu i skrajne uczucia („męczeństwa teatralne, rozpacze udane” $(Z, 32)$, „mniemanych poetów $[. .$.$] mniemane męczarnie, [. .$.$] bezsen-$ sowne zachwyty dla róż, lilii i chabrów"; $Z, 33$ ); a wreszcie (tu znów jesteśmy po stronie generaliów) - za fałsz, czyli rozdźwięk „pomiędzy życiem a słowem poety” $(Z, 32)$. Można by te zarzuty przełożyć na kryteria wartościowania i określać na ich podstawie postulowane cechy poezji. Byłoby to jednak wbrew uzasadnieniom stosowanym przez autora, dla którego najwyższą instancją jest odbiorca, a nie twórca, interesuje go nie tyle tekst literacki, ile siła jego oddziaływania ${ }^{\mathrm{II}}$. Jakkolwiek normy poetyckości są zawsze umotywowane historycznie ${ }^{\mathrm{I2}}$ i trudno rozpatrywać je w izolacji od horyzontu oczekiwań, to w Zarysie Chmielowskiego ustalony został niewątpliwie priorytet oczekiwań nad pytaniami o szanse rozwojowe nowej formuly poetyckiej. Stosując określenia Ryszarda Handke, można by powiedzieć, że „horyzont świadomości” nie został przekroczony w kierunku „, horyzontu rozpoznania" " 3 . Nie bez znaczenia jest tutaj to, że własne nastawienie poznawcze (bądź grupy, którą reprezentuje) Chmielowski zręcznie przypisuje ogółowi i uzwyczajnia nieporozumienia:

Było tedy rzeczą całkiem naturalną, że młodzież pragnąca prawdy, pracująca w imię nauki, mająca przed sobą ważne zagadnienie życia, na które płacz i narzekanie nic pomóc nie mogły, zwróciła się przede wszystkim przeciw tym egotycznym wylewom

II Zob. J. Tomkowski, op.cit., s. 26.

I2 M. Głowiński, Kanony poetyckości i style historyczne, w: O wspótczesnej kulturze literackiej, red. S. Żółkiewski, M. Hopfinger, t. 1, Wrocław 1973.

${ }_{3} \mathrm{R}$. Handke, Kategoria boryzontu oczekiwań odbiorcy a wartościowanie dziet literackich, w: Problemy odbioru i odbiorcy, red. T. Bujnicki, J. Sławiński, Wrocław 1977, s. 95, 97. 
zbyt rozłzawionych marzycieli, co jękiem tylko przemawiać zwykli (Z, 32). Dążnościom tym sprzyjało usposobienie ogółu, ze wstrętem odwracającego się od poezji $(Z, 40)^{\mathrm{I}}$.

W tej sytuacji komunikacyjnej sfera napięć dramatyzuje się szczególnie silnie ${ }^{15}$, bo tak szanując perspektywę odbiorcy, krytyk w istocie unieważniał jego potrzeby, a odpowiedzialność za to unieważnienie przenosił na poetów. Dokonywało się tu też inne ważne przesunięcie. Postulując ,życie życiem ogółu” $(Z, 38)$ czy zrozumienie „nowych potrzeb życia” $(Z, 31)$, a także skuteczność docierania do „serc spragnionych prawdy i postępu" $(Z, 31)$, autor wskazuje w zasadzie nie tyle na konieczność realizacji nowych ideałów poetyckich, lecz potrzeb społecznych. Przypomina lub formułuje nakaz przekroczenia sfery ideałów artystycznych po to, by uczestniczyć w rzeczywistości. Dyskurs o poezji nie wspierał zatem tylko pytań o modele literackości, lecz także o życiowe postawy. Dotyczył sposobów partycypowania w tradycji i modeli uczestnictwa w rzeczywistości.

Rekonstruując atak na poetów z perspektywy dystansu, Chmielowski potwierdza, a nie wyrokuje; powtarza, a nie ustala; podtrzymuje opinie, ale widzi je już w komunikacyjnym uwikłaniu. Przede wszystkim mówi głównie cudzym głosem przytaczając obszerne fragmenty wypowiedzi Adama Wiślickiego (Groch na ścianę) i Elizy Orzeszkowej (Listy o literaturze) oraz przypominając swój własny tekst (Utylitaryzm w literaturze) - lub powołuje się na opinie innych, jak w przypadku odczytu Jana Maurycego Kamińskiego O stosunku poezji do życia społecznego i tekstu Franciszka Krupińskiego Romantyzm i jego skutki. $\mathrm{Z}$ mistrzowskim powodzeniem wyznacza i wyzyskuje autorytet ogółu, powszechnej opinii, głosu większości, co osąd na temat współczesnej poezji czyni przytłaczającym. Zarazem jednak zmienia pozycje nadawcy tekstu, który dysponuje sądami wartościującymi, ale ich autorem tylko bywa. Dyskurs oceniający ma więc nie tylko zmienną dynamikę, ale też ambiwalentną wartość, bo rozproszone autorstwo jednocześnie wzmacnia ją i obniża.

Trzeba jednocześnie pamiętać, że trafnie opisując motywacje młodych, krytyk widzi ich sądy jako uzasadnione sytuacyjnie,

${ }_{4} 4$ Stronę wcześniej autor pisał jednak, myśląc o współczesnym poecie: „jeżeli wymagania i potrzeby społeczne, nie zaś oklaski bezmyślnego tłumu, będą jego przewodnikami: - to utwór jego zadowolni zarówno estetyczne poczucie, jak i prawidła myślenia" (Z, 39; fragment cytatu z Utylitaryzmu w literaturze). Trudno ustalić, gdzie przebiegała u Chmielowskiego granica między świadomym ogółem a bezmyślnym tłumem.

I5 Zob. M. Głowiński, Komunikacja literacka jako sfera napięć, w: Problemy odbioru i odbiorcy, s. 60-70. 
często powierzchowne czy nieprzemyślane. Pierwszy obszernie cytowany sąd na temat poezji poprzedzony został interesującą charakterystyką środowiska „Przeglądu Tygodniowego”, z którego pochodził przywoływany tekst (Groch na ściane):

Odznaczało się ono jedną bardzo ważną cechą, a mianowicie: wielką ruchliwością; nie dbając o wyczerpanie kwestii, o studia gruntowne, muskało wszystkie sprawy, zaciekawiało, pobudzało do mówienia o nich. [...] w „Przeglądzie Tygodniowym” wypisać się było można dowoli, byle krótko a jędrnie $(Z, 33)$.

W innym miejscu natrafiamy na taką diagnozę:

Rozbierając dzieła sobie współczesne pytała się [młodzież - U.K.], jaka jest ich wartość myślowa, jaką prawdę przynoszą one społeczeństwu, jakie mu drogi wskazują, a ponieważ nie odróżniała oczywiście prawdy istotnej od tego, co sama za taką uważała, domagała się więc od poetów tego, aby jej myślami myśleli, jej przekonania podzielali $(Z, 35)$.

Uwagi o aktywności poetów muszą być czytane w kontekście tych słów. Nie osłabia to, co prawda, siły raportu o stanie ówczesnej poezji, ale każe pamiętać o atmosferze intelektualnej, która określała jego ramy. Można odnieść wrażenie, że wypowiedź Chmielowskiego oscyluje między biegunem sytuacyjnego subiektywizmu a próbą obiektywizacji. Ta ostatnia ujawnia się i wtedy, kiedy Chmielowski odnotowuje pozytywne (choć niezbyt udane artystycznie) próby poetyckich odpowiedzi na wyzwania współczesności - Władysław Ordon, Karol Świdziński, Stanisław Grudziński, Adam Asnyk - i wówczas, gdy dystansuje się wobec zbyt ostrej napaści Franciszka Krupińskiego na romantyzm. Ten przykład jest szczególnie ciekawy. Obwinianiu przez autora Romantyzmu i jego skutków poezji romantycznej o to, że stała się przyczyną narodowych nieszczęść, przeciwstawia Chmielowski pozytywną opinię młodych o Panu Tadeuszu jako początku „realnego w twórczości kierunku” $(Z, 45)$. Trudno oprzeć się wrażeniu, że porządki polityki i estetyki spotykają się w wywodzie krytyka, by się - nie znajduję lepszego słowa eufemizować. To ważny sygnał dystansu wobec komunikowania narodowych kwestii wprost. 


\section{Jakim bądź sposobem}

Spróbujmy wykroczyć poza Zarys, mając go ciągle w pamięci. Nie da się mówić w tym miejscu o wszystkich pracach tak płodnego autora, jakim był Chmielowski. Jeśli chodzi o teksty o zamyśle syntetycznym, a nie studia o pojedynczych autorach czy recenzje, to interesującym dopełnieniem Zarysu jest książka Współcześni poeci polscy ${ }^{16}$, a zwłaszcza poprzedzająca ją przedmowa, gdzie sformułowana jest deklaracja:

Chciałem przedstawić $\mathrm{w}$ tym dziełku stan poezji naszej po roku 1863, uwzględniając te osobistości, które w ruchu literackim żywy brały udział, zabierając takie lub inne stanowisko wobec spraw życia narodowego i cywilizacji ogólnoludzkiej ${ }^{17}$.

Trudno oprzeć się wrażeniu, że takie podwójne „wobec” towarzyszyło Chmielowskiemu już w 1881 roku, a to by mogło oznaczać, że niezgoda na „mniemane” cierpienia i męczarnie poetów była tym większa, im bardziej wydawała się nieadekwatna wobec faktycznych cierpień i nieszczęść narodowych. Choć przedmiot refleksji jest ten sam, co poprzednio, to zwraca uwagę zdecydowana zmiana języka, widoczna i w przytoczonym już fragmencie, i wówczas, gdy autor używa określenia „poezja patriotyczna” $(W, 3)$. Jest tu ono zastosowane, trzeba przyznać, dosyć nieprecyzyjnie, bo zdaje się być synonimem poezji w ogóle, a to nieco zaskakuje. Ale uzyskuje w wywodzie krytyka wyraźne wzmocnienie. Chmielowski tak pisze o czasach po 1863 roku:

Ideał narodowy pozostał niewątpliwie ten sam, co i przedtem, ale pogląd na środki za pomocą których miał być urzeczywistniony, uległ zmianie stanowczej. Nie egzaltacją i wybuchami, które przyczyniły się do umniejszenia sił, ale rozumnym rachowaniem się ze stosunkami istniejącymi i pracą powolną, organiczną, miano powetować klęski i w jaśniejszą przyszłość podążyć. Dla marzycielstwa, dla poezji, a nawet dla wielkich haseł, wielkich celów, wielkich natchnień nastąpiło ochłodzenie, łatwo dające się wytłumaczyć zawodami, które przypisywano w znacznej części a czasami nawet wyłącznie oddziaływaniu owych haseł i natchnien $(W, 3)$.

I6 Jan Tomkowski zalicza ją do powstających na przełomie XIX i XX wieku syntez Chmielowskiego (obok Zarysu najnowszej literatury polskiej i szóstego tomu Historii literatury polskiej), które zamykały spory o poezję - op.cit., s. 22.

${ }_{77}$ P. Chmielowski, Wspótcześni poeci polscy. Szkice, Petersburg 1895, s. 1. Dalej: $W$. 
Także kwestia oddziaływania, wywierania wpływu na odbiorcę przedstawiana jest tu $\mathrm{w}$ innych kategoriach, bo Chmielowski mówi o popowstaniowym zapotrzebowaniu na wiersze, „które by porwać mogły za sobą ducha narodu” $(W, 3)$.

Przedmowę do Wspótczesnych poetów polskichmożna by czytać nie tylko jako uzupełnienie, ale też jako komentarz do zagadnień znanych już z Zarysu Chmielowski koryguje powszechne „fałszywe" przeświadczenia $(W, 4)$, jakoby pozytywiści odmawiali poezji prawa bytu, wyjaśniając, że chodziło jedynie o napiętnowanie utworów słabych. Podkreślenia wymaga to, że - tak, jak w Zarysie z 1881 roku - autor wzmacnia swój wywód i zawartą w nim argumentację autocytatem. Został on jednak zupełnie inaczej dobrany niż poprzednio i ma całkowicie inny wydźwięk. W Zarysie przypominany był artykuł Utylitaryzm w literaturze z 1872 roku, gdzie od wszystkich utworów literackich wymagał autor, by stały się „użytecznymi produkcjami” (Z, 39). Przytoczenie $\mathrm{z}$ własnego tekstu traktuje tam Chmielowski jako jeden z przykładów niezgody na poezję. Tym jest ona wyrazistsza, że przypomina krytyk ten swój tekst, o którym Adam Makowski słusznie napisał, że jest „najskrajniejszym - wyjątkowym zresztą dla Chmielowskiego - przejawem programowego prymatu „tendencji” w utworze literackim” ${ }^{18}$. W przedmowie do Wspótczesnychpoetów polskich autor przypomina natomiast swoje przemówienie wygłoszone w 1868 roku na zebraniu kółka młodzieży interesującej się literaturą. Tym razem ma to być przykład podważający opinię o deprecjonowaniu poezji przez młodych. Wypowiadając się jako przedstawiciel młodych, Chmielowski cytuje własny tekst, by udowodnić, że krytykował „mdłość i bezbarwność" $(W, 5)$ współczesnej poezji nie w imię jakości wobec poezji alternatywnych, lecz właśnie w celu ocalenia prawdziwych wartości poetyckich. Słuszności tego, że „poezja uważa się za jeden z wielkich czynników cywilizacji” ( $W, 7)$, krytyk nawet nie próbuje podważać. Przekonanie o niekwestionowanym znaczeniu poezji wybrzmiewa we Wspótczesnych poetach polskich tym silniej, że wyrażane jest w dwojaki sposób. Czytamy tu przede wszystkim:

Poezja, będąc najdoskonalszym wcieleniem ideału w rzeczywistość, spełnia misję cywilizacyjną - oczywiście razem z innymi sztukami pięknymi - w zakresie piękna. W życiu zaś jednostek, jak i ludzkości całej, trzy główne działają prądy, na których cywilizacja dąży do mety. Są to prawda, piękno i dobro. Harmonijne rozwinięcie tych trzech światowładnych idei winno być dążeniem każdego człowie-

I8 A. Makowski, op.cit., s. 147. 
ka, bo ono o jego losie stanowi. Stąd się już jasno pokazuje, że oddanie piękna jest zarówno ważne w ogólnej cywilizacji, jak i rozwój prawdy i dobra. Poeci mają tu tę wyższość, nad innymi, że ich czarowna mowa latwiej sięga do głębi serc naszych, niż sucha prawda w abstrakcyjnych formach wypowiedziana. Ale też na nich złożona wielka odpowiedzialność wobec społeczności $(W, 7)$.

Intelektualny rygor głosu kompetencji wymaga jednak wsparcia formułą nostalgii. A to odsłania kompensacyjne motywacje oczekiwań wobec poezji i podpowiada, że krytyka epigońskich nastrojów ckliwego smutku, poza wszystkimi innymi wskazywanymi już uzasadnieniami, mogła też wyrastać z utajonej niezgody na własne tęsknoty, które inni zaspokajali w sposób niewłaściwy czy nawet niegodny. By nie powiedzieć - niegodziwy, biorąc pod uwagę nieadekwatność egotycznego pesymizmu wobec faktycznych powodów do cierpienia, któremu młodzi za wszelką cenę nie chcieli się poddać ${ }^{19}$.

Aż serce się ściska na tę profanację boskiej poezji, której tony kołysały nasze dziecięctwo, która powinna być wsparciem i podnietą na ciernistej drodze żywota. A propos tejże ciernistości rzeczą jest uderzającą, że prawie wszyscy poeci patrzą na swój zawód jako na nieprzerwany ciąg poświęcenia i ofiar $\mathrm{z}$ ich strony, a obojętności i zakamieniałej twardości serc ze strony czytelników $(W, 7)$.

Można zatem przyjąć, że Chmielowskiemu chodziło nie tylko o zapis antagonizmu, ale też o szyfrowanie dramatu odmowy. Młodzi, jak można mniemać po lekturze tekstów krytyka, nie tylko bowiem zakwestionowali wartość współczesnej poezji, ale czynili to w sytuacji, w której sobie samym odmówili prawa do (także poetyckich) wzruszeń. Znaczenie tego tropu potwierdza dyskusja, która toczyła się wokół Zarysu.

Trudno oczywiście wyłuskiwać spór o „rymówki” $(W, 5)$ i o poezję z wielogłosowej polemiki, w której skoncentrowano się przede wszystkim na przecenieniu przez Chmielowskiego znaczenia walki „starej” i „młodej” prasy oraz cywilizacyjnej roli roku 1864. Nie miejsce tu, by tę polemikę przypominać. Ale czas, by problem oceny aktywności poetów umieścić w jej kontekście. Wybieram jeden tylko przykład - jak sądzę, ważny. Mam na myśli wypowiedź Bronisława Chlebowskiego, przed-

I9 Trafnie pisał o tym Jan Tomkowski: „W serii artykułów ogłoszono, iż cierpienia, o jakich piszą poeci, są nieprawdziwe, a uczucia przygnębienia i rozpaczy zmyślone. Poeci tworzą ponure wiersze, bo tak każe im konwencja, a nie własne doświadczenia życiowe" - op.cit., s. 27. 
stawiciela krytyki pozytywistycznej, reprezentującego jej wariant - nazwijmy to - zrównoważony. Odpowiadając na zarzuty stawiane Chmielowskiemu przez „Bibliotekę Warszawską” a kumulujące w sobie typowe sądy na temat postawy "młodych” (ekspansywność nowego modelu cywilizacyjnego, wejście na pole „eksploracji politycznych” ${ }^{20}$ ) - pisał:

Dążenie do ustalenia naruszonej równowagi wywołuje wtedy pojawienie się nowych pojęć i uczuć, nowych idei i ideałów, które odwracają naszego ducha od apatycznego rozpamiętywania swych cierpień, strat i zawodów i zniewalają do nowej działalności, do rozwoju niewyczerpanych jej zasobów. Proces ten nie od razu i niejednakowo we wszystkich odbywa się umysłach, zależy bowiem zarówno od stopnia spójności poprzednich grup pojęciowych, jak i od siły bodźca, tkwiącego w zranionym i wzburzonym uczuciu. Cierpienie w starszym wieku przygnębia i obezwładnia, w młodszych zaś sercach budzi rozpaczliwą energię i pragnienie zniesienia tego stanu jakim bądź sposobem. Człowiek dojrzały szuka na nie lekarstwa w czasie; młodzieniec gotów rozpalonym żelazem stłumić ból serca. Rzecz naturalna, iż utraciwszy dawne ideały, młode umysły gorączkowo szukały nowych, że na miejsce $\mathrm{z}$ latwością rozbitych przez burzę grup luźno spojonych pojęć, chciały jak najprędzej wytworzyć inne, silniejsze i doskonalsze, mogące zrównoważyć cierpienia ich serc i rzucić światło na ciemności, śród których nie mogli dojrzeć dróg przyszłych. Widząc, że wyobrażenia czerpane $\mathrm{z}$ własnej literatury, że dotychczasowe pojmowanie przeszłości narodu i jego przyszłych przeznaczeń okazały się mylnymi, że dotychczasowa filozofia i nauka rodzima nie wystarczały wobec zmienionych warunków i stosunków bytu społecznego - zwrócono się do rezultatów umysłowej pracy Zachodu i z gorączkową skwapliwością chwytano wszystko, co podpadało pod ręce, a zwłaszcza te teorie, poglądy i hipotezy, które uderzały młodą wyobraźnię jaskrawym przeciwieństwem z poprzednio panującymi, które imponowały krańcową bezwzględnością i śmiałością wyprowadzonych konsekwencji ${ }^{2}$.

„Budzili do życia jak umieli i jak mogli” ${ }^{22}$, dopowiada krytyk. I dlatego - uzupełnijmy - z pasją rzucili się na tych, którzy banalizowali ból. A patrząc z drugiej strony - deprecjonowali wartość życia w teraźniejszości.

2 Wiadomości bieżace, naukowe, literackie, artystyczne i społeczne, „Biblioteka Warszawska" 1881, t. 3, s. 157.

${ }_{21}$ B. Chlebowski, Przeglad piśmienniczy. „Biblioteka Warszareska”, „Niwa”, „Ateneum”, kwartał III 1881 r., „Tygodnik Ilustrowany” 1881, nr 309, s. 347.

${ }^{22}$ Ibidem, s. 348. 
Wydaje się, że dopiero poza tą emocjonalną rozprawą mogły dokonywać się próby opisu czy nawet zrozumienia utworów poetyckich. To dlatego widać tak dużą różnicę emocjonalną między syntetycznymi uwagami części pierwszej a szczegółowymi uwagami pomieszczanymi w części drugiej wszystkich wersji (wydań) Zarysu. Przybywa przykładów, rozwagi i aprobaty. We Wspótczesnych poetach polskich okazuje się, że można czytać poezję co prawda nie bezkrytycznie, ale też nie tylko pod presją uprzedzeń. Bez - jawnego i tajonego - obwiniania.

\section{Zamiast (zakończenia)}

Powróćmy do Zarysu, a w zasadzie do zamieszczonego w nim autocytatu z Utylitaryzmu w literaturze. Po latach Chmielowski skomentował swój artykuł i skorygował zawarte w nim poglą$\mathrm{dy}^{23}$. Wydaje się ważne, że uwagi dotyczą poezji. Do ponownego namysłu sprowokowały go słowa: „Precz więc z bezświadomym natchnieniem! Precz ze wszystkimi głupstwami, które mamiąc poetów, wskazywały im łatwą drogę próżniactwa i duchowego ospalstwa” ${ }^{24}$. Refleksja krytyka znów ulega rozwarstwieniu. Podtrzymując potępienie rzucone na "próżniactwo i ospalstwo", dziwi się on jednocześnie własnej niechęci wobec „bezświadomego natchnienia":

Dziś bym tego okrzyku: Precz z beświadomym natchnieniem! wcale nie powtórzył; i dziwię się nawet nieco, żem wówczas go użył, kiedym przecie już znał teorię „skojarzeń utajonych”, bo o nich pisałem w tej samej „Niwie” w Genezie fantazji. Widocznie prąd utylitarystyczny był wówczas tak silny, że mi przesłonił wskazówki psychologii doświadczalnej ${ }^{25}$.

Sądy na temat poezji zapisane w Zarysie były zatem tak nieprzychylne, jak były zdeterminowane. Ważniejsza wydaje się jednak inna kwestia - możliwości potraktowania ponawianych przez Chmielowskiego odwołań do poezji jako indywidualnego idiolektu służącego dynamizowaniu dyskursu krytycznego. Ewoluowanie wypowiedzi o poezji - dla których wewnętrznym punktem odniesienia pozostaje Zarys - przebiega u Chmielow-

23 P. Chmielowski, Z rozmyślań krytyka, w: idem, Pisma krytycznoliterackie, t. 1; pierwodruk: Stowackiemu. Jednodniówka ku czci Słowackiego, Kraków [1904].

${ }_{24}$ Cyt. za: P. Chmielowski, Z rozmyślań krytyka, s. 219.

25 Ibidem, s. 220. 
skiego od oceny do przykładu. We Współczesnych poetach polskich tak charakteryzuje krytyk swoją metodę badawczą:

Punkt tylko wyjścia jest wszędzie jednakowy: objawy poezji rozpatrywałem zawsze nie tylko z estetycznej strony, ale i ze spolecznego stanowiska. Przeważna część uwag odnosi się nawet do tego drugiego, gdyż ideę łatwo w krótkich słowach przedstawić; nad formą trzeba by się długo rozwodzić. Z a miast wykrzykników uwielbienia lub potępienia, odnoszących się do rzeczy, które ogółowi czytelników zazwyczaj są obce, wolałem przytoczyć wiersz jakiś lub też zwięźle sąd swój o stronie artystycznej utworu zanotować $(W, 13-14)$.

Symbolicznym zenitem tych przemian wydaje się fragment Spótczucia psychologicznego, gdzie doświadczenie lektury poezji staje się wzorem i miarą doskonałej praktyki krytycznej:

Może się komuś wydać dziwactwem, a nawet kuglarstwem, ale kto kiedy $\mathrm{z}$ prawdziwym przejęciem odczytywał dzieła wielkich poetów, ten nie będzie mógł zaprzeczyć, iż mimo woli działo się z nim to, co przedstawiłem jako obowiązek badacza, pragnącego wchłonąć utwór badany bez uszkodzenia go jednak ${ }^{26}$.

Patrząc z tego punktu można uznać - raczej sugerując niż przesądzając - że radykalne wartościowanie poezji w Zarysie było językiem krytycznej niedojrzałości lub etapem poszukiwania języka krytyki.

\section{URSZULA KowALCZUK}

\section{Valuation of poetry in "Zarys literatury polskiej z ostatnich lat szesnastu” by Piotr Chmielowski. A handful of perspec- tives to consider}

The article analyses the mode of establishing and recording the process of poetry valuation in Zarys literatury polskiej z ostatnich lat szesnastu [An outline of the literature of the last sixteen years] written by Piotr Chmielowski, as well as the textual strategies of the author that modeled the transformations in the discourse of the author. It is proved in the article that in the Chmielowski's disquisitions the problem of evaluation is just as important as the evaluation as a problem. The evaluation

${ }_{26}$ P. Chmielowski, Spótczucie psychologiczne w badaniach bistorycznoliterackich, w: idem, Pisma krytycznoliterackie, t. 1, s. 208-209; pierwodruk: Pamiętnik III Zjazdu Historyków Polskich w Krakowie, urządzonego przez Towarzystwo Historyczne Lwowskie w dniach 4, 5 i 6 czerwca 1900, I. Referaty, Sekcja II. 
of poetry conducted by the critic was an element of self-identification of the generation of "young poets" that he himself represented, as well as a proof for their longing for grand poetry, discomfort resulting from lack of authority figures and difficulties in expressing one's own or/and national suffering. The use of the so-called "argument of poetry" has been recognized here as a distinctive feature of Chmielowski's idiolect that serves to dynamize his critical writings.

Key words: poetry, evaluation, evaluative discourse, exclusion, suffering.

Urszula Kowalczuk - zatrudniona w Instytucie Literatury Polskiej Wydziału Polonistyki Uniwersytetu Warszawskiego. Zajmuje się badaniem: dziewiętnastowiecznej świadomości w kontekście przemian kultury, literackich odpowiedzi na wyzwania nowoczesności i tradycji, pisarstwa Stanisława Brzozowskiego. Autorka książek: Felicjan Faleński. Treórczość i obecność (2002); Powinność i przygoda. Pisarze polscy drugiej połowy XIX wieku wobec kultury renesansu (2011).

e-mail: u.kowalczuk@uw.edu.pl 